\title{
ESTIMATION OF THE THICKNESS OF DIFFUSIONAL BOUNDARY LAYER FROM KINETIC DATA OF FILM DYEING
}

\author{
By Takao Shibusawa and Tomomiti Endo \\ (College of Technology, Gunma University 1-5*1, \\ Tenjin-cho, Kiryu-shi 376, Japan)
}

\begin{abstract}
The values of diffusion coefficient of non-ionic dyes in nylon 6 and polyester film $\left(D_{f}\right)$ were evaluated by analyzing the concentration profiles of the dyes in the films and the kinetic data of the film dyeing (or desorption from the film). For many cases, the values of $D_{f}$ evaluated by the both method agreed well each other. However, when the dye having high affinity on nylon 6 film was desorped under an insufficient agitation, the values of $D_{f}$ from the kinetic data sometimes appreciably smaller than the corresponding $D_{i}$ from the profiles.

The values of boundary layer parameter $(L)$ in the film dyeing were estimated by the curve fitting to the kinetic data of the dyeing by use of a relevant Newman's equation coupled with $D_{f}$ determined from the profile.

The thickness of the diffusional boundary layer $\left(\delta_{D}\right)$, estimated from the value of $L$, decreased rapidly as the rate of agitation of the specimens in the bath was increased; i. e., the values of $\delta_{\mathrm{D}}$ estimated at $40-90^{\circ} \mathrm{C}$ under the reciprocation $(30 \mathrm{~mm})$ of the specimen of $0,30,80$ and 146 strokes/min ranged $20-80,5.9-18.5,14-15$ and $0.2-0.7 \times 10^{-3} \mathrm{~cm}$, respectively.

It was found that when the film dyeing carried out under the vigorous agitation, such as at the flow rate of $14.6 \mathrm{~cm} / \mathrm{sec}$ near the film surface, the resistance to the dye transport across the diffusional boundary layer gives little effect on the rate of the dyeing, in contrast to the dyeing of fabrics or yarns.
\end{abstract}

\section{INTRODUCTION}

In practical dyeing of fiber assemblies, such as yarn packages or fabrics, the flow rate of dye liquor through the spaces between the individual fibers in yarns is usually low ${ }^{1)}$; the thickness of the diffusional boundary layer $\left(\delta_{D}\right)$ adjacent to the outer surface of the fibers is fairly large. In such dyeing system, the rate of dyeing is controlled by both the diffusion of dye across the stag. nant solution layer and that into the fiber itself. ${ }^{2)}$ Therefore, the estimation of the values of $\delta_{\mathrm{D}}$ for various dyeing system is of interest to understand the problems concerning the rate of practical dyeing.

We have estimated the numerical values of $\delta_{D}$ in the dyeing of nylon and polyester yarns with non-ionic dyes by analyzing the kinetic data of dyeing ${ }^{3}$, where the estimation was based on the assumption that the individual fibers are uniformly accessible to the liquor flow. However, the local velocity of liquor flow close to the surface of the individual fibers vary at different point of the fiber assemblies, therefore, the values of $\delta_{\mathrm{D}}$ thus estimated may be taken as the average thickness for the equivalent diffusional boundary layer around individual fibers ${ }^{4)}$; the values seems to indicate that the sorption delay corresponding to the resistance to the dye transport across the diffusional boundary layer of thickness of $\delta_{\mathrm{D}}$ will occur in those dyeing systems. It seems that the value of $\delta_{\mathrm{D}}$ close to actual one can be obtained by analyzing the kinetic data of dye sorption by films or mono filament fibers if we consider the uniformity of fluid flow near the surface of these substrates.

In the present paper, the values of $\delta_{\mathrm{D}}$ in the dyeing of nylon and polyester films with non-ionic dyes will be estimated from the kinetic data of the sorption (or desorption) of the dyes by the films and the diffusion coefficients of the dyes in the films $\left(D_{1}\right)$ determined from the concentration profiles of the dyes in the films, and the effects of agitation of the film specimens in dye bath 
on $\delta 0$ will also be discussed.

\section{THEORY}

Rate of sorption of a non-ionic dye by a homogeneous film surrounded with diffusional boundary layer of thick. ness $\delta \mathrm{D}$ from an infinite dye bath is expressed by eq. $1^{5,6)}$.

$$
\frac{M_{t}}{M_{\infty}}=1-\sum_{n=1}^{\infty} \frac{2 L^{2} \exp -X}{B_{n}^{2}\left(B_{n}^{2}+L^{2}+L\right)}, \quad X=\frac{D_{s}}{l^{2}} t
$$

where $M_{t}$ and $M_{\infty}$ are the amount of dye taken up by the film at time $t$ and at equilibrium, respectively, $D_{f}$ is concentration independent diffusion coefficient of the dye in the film, $l$ is the half-thickness of the film, $B_{n}$ 's are positive non-zero roots of the equation $B_{n} \times \tan \left(B_{n}\right)-L$ $=0$ and $L$ is boundary layer parameter given by eq. $2 .{ }^{2)}$

$$
L=\frac{D_{s} l}{D_{f} K \delta D}
$$

were $D_{s}$ is the diffusion coefficient of the dye in the boundary layer or in the bulk solution, $K$ is the partition coefficient of the dye between the solution and the film. The smaller value of $\mathrm{L}$ indicates the larger sorption delay due to the resistance to the dye transport across the difusional boundary layer.

Non-ionic dye system in which $D_{1}, D_{s}$ and $K$ vary very little with dye concentration. Hence, the values of $L$ and

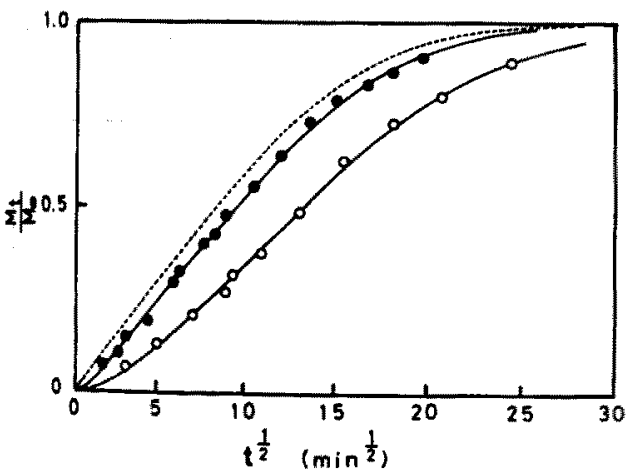

Fig. 1 Rates of desorption of Dye 1 from nylon 6 film into water at $40^{\circ} \mathrm{C}$.

Experimental points, $\bigcirc$ and $O$ were measured without agitation and under the agitation of 80 strokes/min, respectively.

The curves passing through the experimental points $O$ and - were calculated by eq. 1 using $L=3.06, D_{i}=4.86 \times 10^{-9} \mathrm{~cm}^{2} / \mathrm{min}$ and $L=19.9$. $D_{f}=4.70 \times 10^{-9} \mathrm{~cm}^{2} / \mathrm{min}$, respectively. The dotted line, $\cdots \cdot \cdot$, was calculated similary using $L=$ $\infty$ and $D_{f}=4.97 \times 10^{-9} \mathrm{~cm}^{2} / \mathrm{min}$.
$D_{f}$ in a film dyeing can be estimated from the kinetic data of sorption (or desorption) of a non-ionic dye by the film by means of a curve fitting technique using eq. 1 as shown in Fig. 1. In general, the most reliable value of $D_{f}$ in a film is obtained from the concentration profile of dyes in the film; the profile can be determined exactly by means of the film roll methods developed by Sekido at al. ${ }^{7)}$ Therefore, by comparing the value of $D_{f}$ estimated from the kinetic data of sorption with that from the profile, one can verify the validity of the values of $L$ and $D_{f}$ obtained from the kinetic data by the curve fitting. The value of $\mathrm{K}$ for a certain dyeing system is measurable ex. perimentally and $D_{s}$ can be estimated from the van der Waals volume of the dye $\left(V_{w}\right)$ by eq. $3^{8)}$

$$
\log \left(\frac{T}{\eta D_{s}}\right)=0.65787 \log V_{w}+6.37439
$$

where $\mathrm{T}$ and $\eta$ are the absolute temperature and viscosity of solution, respectively.

Hence the value of $\delta \mathrm{D}$ can be estimated from ex. perimental $K, D_{f}$ and the kinetic data of film dyeing with non-ionic dyes from an infinite bath.

\section{EXPERIMENTAL}

\subsection{Materials}

The film used were nylon 6 (thickness $=c a .0 .0027 \mathrm{~cm}$. prepared by Unitika Ltd.) and poly-ethylene terephtha. late (thickness $=0.0012 \mathrm{~cm}$. prepared by Toray Ltd; here after abbreviated as polyester film). They were treated in water at $95^{\circ} \mathrm{C}$ for $25 \mathrm{~h}$ prior to dyeing.

The dyes used were the same as used in previous paper. ${ }^{3)}$ The structure of the dyes and van der Waals volume are shown in Table 1.

\begin{tabular}{|c|c|c|c|}
\hline No. & $\begin{array}{c}\text { Dye } \\
\text { Structure }\end{array}$ & M. W. & $\begin{array}{c}\mathrm{V}_{\mathrm{W}}{ }^{\mathrm{A})} \\
(\mathrm{ml} / \mathrm{mol})\end{array}$ \\
\hline 1 & & 285.3 & 160.1 \\
\hline 2 & & 299.4 & 171.2 \\
\hline 3 & & 238.2 & 123.9 \\
\hline
\end{tabular}

Table 1 Structure and van der Waals volume of dyes used.

*) van der Waals volume estimated by means of Bondi's method. $^{8.9)}$ 


\subsection{Measurements of rate of desorption and sorption}

Nylon 6 film was evenly dyed with Dye 1 and 2, then cut into small pieces $(2.0 \times 2.5 \mathrm{~cm})$. Each film was held between the stainless steel plates with rectangular win. dow of $1 \mathrm{~cm} \times 2 \mathrm{~cm}$ as shown in Fig. $2 \mathrm{~A}$, then pretreated in water at $0-5^{\circ} \mathrm{C}$ for $5 \mathrm{~min}$. After that, the specimen was desorped in $1000 \mathrm{ml}$ of water at required temperature $\left(0 \pm 0.1^{\circ} \mathrm{C}\right)$ for relevant time using the apparatus shown in Fig. 2B; the rate of agitation of the specimen was controlled by changing the frequency of reciprocation of the holder up-to downward. To maintain the zero dye concentration in the bath, $0.5 \mathrm{~g}$ of active carbon fiber (prepared by Osaka Gas Ltd.) was added in the bath.

Polyester film was pretreated in water for $10 \mathrm{~min}$ at the same temperature of the dyeing, just after that, the film was dyed in $1000 \mathrm{ml}$ of an aqueous fine dispersion of Dye 3 containing $0.5 \mathrm{~g}$ of pure dye $\mathrm{s}^{3)}$ by the similar manner as in the desorption described above.

The relative amount of dye on the films, $M_{t} / M_{\infty}$. was estimated from the difference in the optical density of film at a relevant wavelength before and after the dyeing (or desorption); a good linear relation between the amount of dye on the film and the optical density of the dyed film was observed for each dye used.

Dye 1 and 2 on nylon 6 film are sensitive to light, cistrans isomerization of the dyes will occur even on standing the dyed films near a window for a few minutes. The isomerization is accompanied by a spectral change with

(B)

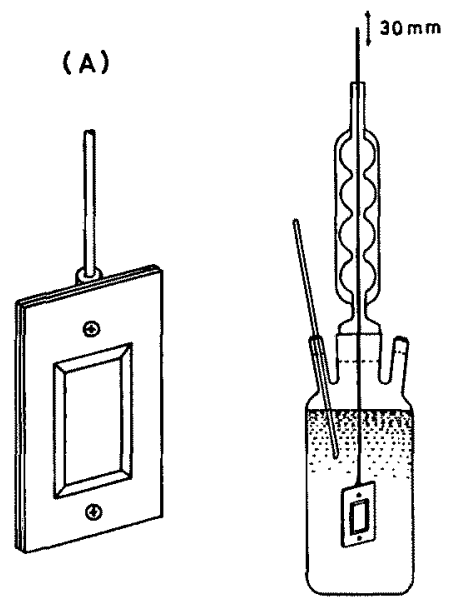

Fig. 2 Apparatus used for the dyeing and desorption of films isosbestic points. Therefore, the optical density of these films was determined at the wavelengh of an isosbestic point (Dye 1: $383 \mathrm{~nm}$ and Dye 2: $379.5 \mathrm{~nm}$ ). The optical density of the polyester film dyed with Dye 3 was measured at $556 \mathrm{~nm}$ which was an absorption maximum of the dye on the film in visible region.

The optical measurements were made on a Simadzu UV-150-02 spectrophotometer and calculations were made on an NEC-PC.VX. 0 personal computer.

\section{RESULTS AND DISCUSSION}

Fig. 3 shows the concentration profile of Dye 1 in the nylon $6 \mathrm{film}$; the curve passing through the experimental points was calculated by eq. 4 using $D_{f}(4.84 \times$ $10^{-9} \mathrm{~cm}^{2} / \mathrm{min}$ ) obtained by the curve fitting to the ex. perimental profile using eq. 4 . The agreement between the experimental points and the calculated curve is fairly well.

$$
\frac{C}{C_{0}}=\operatorname{erfc} \frac{x}{2\left(D_{r} t\right)^{1 / 2}}
$$

- where $\mathrm{C}$ and $\mathrm{C}_{0}$ are the concentration of the dye at a distance $x$ from the surface of the substrate and at the surface, respectively, $t$ is the time of diffusion.

Similar profiles were also obtained for Dye 2 and 3 in nylon $6 \mathrm{film}$ and in polyester film, respectively. Hence, the standard values of $D_{f}$ of each dye at various tempera. tures were determined from the profiles having $C_{0}$ close

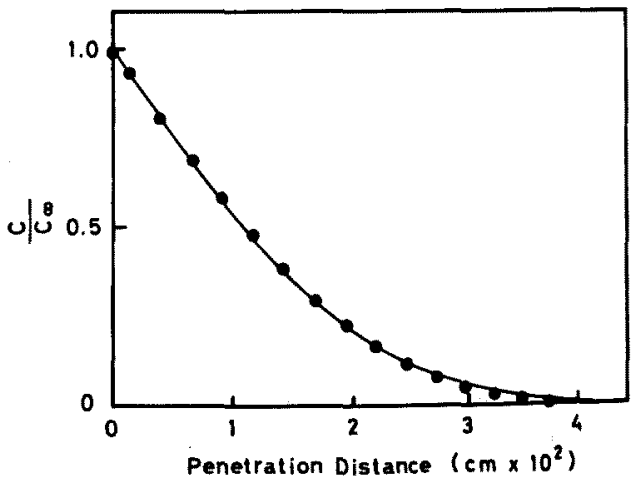

Fig. 3 Diffusion of Dye 1 in nylon 6 film at $40^{\circ} \mathrm{C}$ for $25920 \mathrm{~min}$, a concentration profile measured by means of the film roll method.

: experimental point. _ : calculated by eq. 4 using $D_{f}=4.84 \times 10^{-9} \mathrm{~cm}^{2} / \mathrm{min}$.

The concentration of the dye on the film at the sorption equilibrium was taken as the dye concentration at the film surface. 
Table 2 Comparison of Diffusion coefficient of the nonionic dyes in films determined from the concen. tration profile with those calculated from the kinetic data of dyeing.

\begin{tabular}{|c|c|c|c|c|c|}
\hline \multirow[b]{2}{*}{ Dye } & \multirow[b]{2}{*}{$\begin{array}{l}\text { Temp } \\
\left({ }^{\circ} \mathrm{C}\right)\end{array}$} & \multirow[b]{2}{*}{$\begin{array}{l}\text { Stirring } \\
\text { (stokes/min) }\end{array}$} & \multirow{2}{*}{$\begin{array}{c}(\mathrm{A})^{\mathrm{e})} \\
\mathrm{D}_{1} \times 10^{9} \\
\left(\mathrm{~cm}^{2} / \mathrm{min}\right)\end{array}$} & \multicolumn{2}{|c|}{$(B)^{d)}$} \\
\hline & & & & $\begin{array}{c}\mathrm{D}_{\mathrm{f}} \times 10^{9} \\
\left(\mathrm{~cm}^{2} / \mathrm{min}\right)\end{array}$ & L \\
\hline \multirow{3}{*}{$1^{a)}$} & & 0 & \multirow{3}{*}{4.84} & 4.86 & 3.06 \\
\hline & 40.0 & 30 & & 4.72 & 13.9 \\
\hline & & 80 & & 4.70 & 19.9 \\
\hline \multirow{9}{*}{$2^{\text {a) }}$} & \multirow{3}{*}{40.0} & 30 & \multirow{3}{*}{4.07} & 3.08 & 21.4 \\
\hline & & 80 & & 3.35 & 17.1 \\
\hline & & 146 & & 4.16 & 92.9 \\
\hline & 50.0 & 30 & 10.0 & 8.39 & 18.2 \\
\hline & 60.0 & 30 & 24.9 & 19.4 & 13.5 \\
\hline & \multirow{2}{*}{70.0} & 30 & \multirow{2}{*}{55.0} & 45.3 & 11.8 \\
\hline & & 146 & & 57.5 & 62.5 \\
\hline & \multirow{2}{*}{80.0} & 30 & \multirow{2}{*}{125} & 9.91 & 9.49 \\
\hline & & 146 & & 130 & 62.6 \\
\hline $3^{b)}$ & 95.0 & 0 & 0.374 & $0.373_{9}$ & 282 \\
\hline
\end{tabular}

1) Desorption from nylon 6 film into an aqueous bath maintained at zero dye concentration,

b) Sorption by polyester film from an infinite bath.

c) Determined from the concentration profiles measured by the film roll method.

d) Calculated from the kinetic data of the sorption or the desorption.

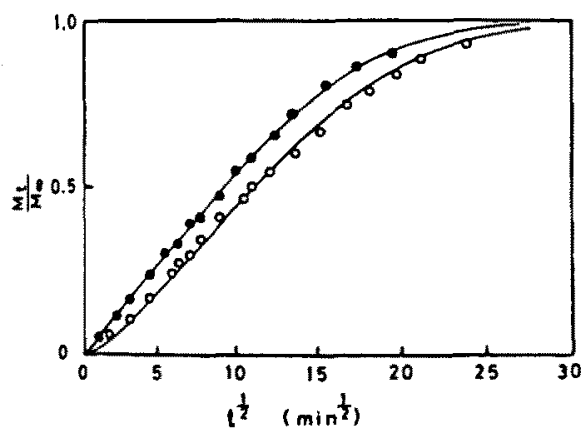

Fig. 4 Rates of desorption of Dye 2 from nylon 6 film into water at $40^{\circ} \mathrm{C}$

Experimental point, $\bigcirc$ and $O$ were measured under the agitation of 30 and 146 strokes $/ \mathrm{min}$. respectively.

Curves passing through the experimental points $O$ and $O$ were calculated by eq. 1 using $\mathrm{L}=21.4, \mathrm{D}_{\mathrm{f}}=3.08 \times 10^{-9} \mathrm{~cm}^{2} / \mathrm{min}$ and $\mathrm{L}=92.9$, $\mathrm{D}_{l}=4.16 \times 10^{-9} \mathrm{~cm}^{2} / \mathrm{min}$, respectively.

Dotted line, ...... was calculated by eq. 1 using $L=\infty$ and $D_{f}=4.07 \times 10^{-9} \mathrm{~cm}^{2} / \mathrm{min}$. to $\mathrm{M}_{\infty}$ in the corresponding sorption or desorption $\mathrm{ex}$. periments. The values of $D_{f}$ thus determined are given in the column (A) in Table 2.

Figs. 1 and 4 show the effect of agitation of the specimen on the rate of desorption of Dye 1 and 2 from nylon 6 film, respectively. Each curve passing through the experimental points $(0,0)$ was calculated by eq. 1 using $\mathrm{L}$ and $\mathrm{D}_{\mathrm{f}}$ obtained by the curve fitting to the correspond. ing kinetic data. The deviation of the experimental points from the theoretical curve was very small for each dyeing system. The desorption delay at the initial stage decreased rapidly as the rate of the agitation was increased. These findings indicate that the desorption delay is ascribed to the resistance to the dye transport across the diffusional boundary layer. The film used seemed to have no surface barrier layers for the dye diffusion, since the diffusion behavior of the dye in the film approached to that of normal Fickian (Fig. $4, \cdots \cdots$ ) as the rate of the agitation of the specimen was increased up to 146 strokes/min (Fig. 4 ,

Hence the values of $L$ and $D_{f}$ were estimated from the kinetic data of the dye desorption (or sorption) by the curve fitting using eq. 1 as given in the column (B) of Table 2. The values of $D_{f}$ of Dye 1 and 3 obtained from the kinetic data agreed with the corresponding $D_{i}$ 's from the profile, given in the column (A), within ca. $3 \%$ deviation, indicating that the values of $L$ for Dye 1 and 3 given in the column $(B)$ are almost valid. The value of $D_{f}$ should be independent of the rate of the agitation, however, for Dye 2 , the values of $D_{f}$ from the kinetic data decreased as the rate of agitation was decreased. The values of $D_{f}$ of Dye 2 from the kinetic data measured under the agitation of 146 strokes/min were only slightly larger than the corresponding $D_{f}$ values from the profile. On the other hand, the values of $D_{f}$ from the kinetic data measured under the agitation below 80 strokes $/ \mathrm{min}$ were appreciably smaller than the corresponding $D_{f}$ values from the profile. The reason for the discrepancy in the value of $D_{f}$ has not been clarified yet, however, this indicates that in some cases, the reasonable value of $L$ can not be estimated only from the kinetic data of sorption or desorption. It seems that the curve fitting to the kinetic data of the desorption by using eq. 1 coupled with $D_{1}$ from the profile gives a more reasonable value of $L$, since the most reliable value of $D_{\ell}$ is usually obtained from the profile. 


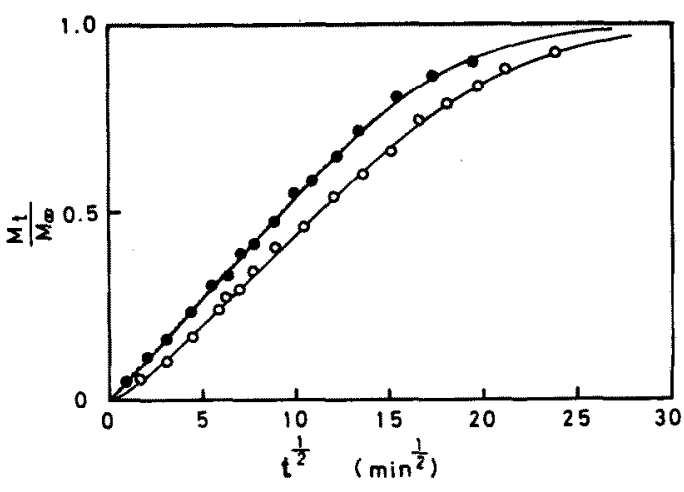

Fig. 5 Estimation of boundary layer parameter L by the curve fitting to the rate of desorption data of Dye 2 from nylon 6 film at $40^{\circ} \mathrm{C}$.

Experimental points, $O$ and 1 were measured under the agitation of 30 and 146 strokes/min, respectively.

The curves passing through the experimental points $\bigcirc$ and $O$ were obtained by the curve fitting to each set of the kinetic data using eq. 1 and $D_{f}=4.07 \times 10^{-9} \mathrm{~cm}^{2} / \mathrm{min}$ which is the value of diffusion coefficient of the dye in the film de. termined from the concentration profile of the dye in the film.
Fig. 5 shows the curve fitting thus made to the same data as given in Fig. 4, the deviation of each ex. perimental point from the curve calculated by using eq. 1 and $D_{f}$ from profile $\left(4.07 \times 10^{-9} \mathrm{~cm}^{2} / \mathrm{min}\right)$ was somewhat larger than that in Fig. 4, however considering the high reliability of $D_{i}$ from the profile, the value of $L$ for each dyeing system was estimated from the kinetic data given in Tables 3,4 and $D_{1}$ from the profile. The values of $L$ thus determined are given in the Table 5 from which the value of $\delta \mathrm{D}$ for each dyeing system was calculated as given in the last column in the same Table.

When a plate is placed in a laminar flow of velocity $V_{0}$, the average thickness of the diffusional boundary layer $\left(\delta_{\mathrm{D}}\right)$ adjacent to the surface of the plate is express ed by eq. $5^{1)}$

$$
\delta_{\mathrm{D}}=1.47\left(\frac{\mathrm{D}_{\mathrm{s}}}{\nu}\right)^{\frac{1}{3}}\left(\frac{\nu \lambda}{\mathrm{V}_{0}}\right)^{\frac{1}{2}}
$$

where $\nu$ is kinematic viscosity, $\nu=\mu / \rho, \mu$ is viscosity of fluid, $\rho$ is density of the fluid and $\lambda$ is the length of the plate. When $\mathrm{V}_{0}=0, \delta_{\mathrm{D}}$ is not $\infty$ but a limiting value $\delta_{\mathrm{D}}^{*}$.

For the present study, if we let $\lambda=2 \mathrm{~cm}$, the length of the rectangular window of the film folder, and $V_{0}$ is the average velocity of the reciprocation of the specimen, we

Table 3 Effect of agitation of specimen on the rate of desorption of Dye 1 and 2 from nylon 6 film at $40^{\circ} \mathrm{C}$.

\begin{tabular}{|c|c|c|c|c|c|c|c|c|c|c|c|c|}
\hline Dye & \multicolumn{6}{|c|}{1} & \multicolumn{6}{|c|}{2} \\
\hline $\begin{array}{c}\text { Agitation } \\
\text { (strokes/min) }\end{array}$ & \multicolumn{2}{|r|}{0} & \multicolumn{2}{|r|}{30} & \multicolumn{2}{|c|}{80} & \multicolumn{2}{|c|}{30} & \multicolumn{2}{|c|}{80} & \multicolumn{2}{|c|}{146} \\
\hline \multirow{19}{*}{ Kinetic Data } & $\begin{array}{l}\text { Time } \\
\text { (min) }\end{array}$ & $M_{1} / M_{\infty}$ & $\begin{array}{l}\text { Time } \\
(\min )\end{array}$ & $M_{t} / M_{\infty}$ & $\begin{array}{l}\text { Time } \\
(\min )\end{array}$ & $M_{\mathrm{t}} / \mathrm{M}_{\infty}$ & $\begin{array}{l}\text { Time } \\
\text { (min) }\end{array}$ & $M_{4} / M_{\infty}$ & $\begin{array}{l}\text { Time } \\
(\min )\end{array}$ & $\mathrm{M}_{1} / \mathrm{M}_{\infty}$ & $\begin{array}{l}\text { Time } \\
\text { (min) }\end{array}$ & $M_{1} / M_{\infty}$ \\
\hline & 10 & $0.071_{6}$ & 3 & 0.066 & 3 & $0.073_{7}$ & 3 & $0.058_{2}$ & 3 & $0.062_{1}$ & 1 & $0.048_{5}$ \\
\hline & 25 & 0.133 & 10 & 0.152 & 7 & 0.108 & 10 & 0.104 & 7 & $0.093_{4}$ & 5 & 0.114 \\
\hline & 50 & 0.212 & 20 & 0.218 & 10 & 0.150 & 20 & 0.168 & 10 & 0.108 & 10 & 0.163 \\
\hline & 80 & 0.275 & 35 & 0.293 & 20 & 0.200 & 35 & 0.241 & 20 & 0.171 & 20 & 0.236 \\
\hline & 87 & 0.319 & 40 & 0.307 & 35 & 0.295 & 40 & 0.274 & 35 & 0.236 & 30 & 0.303 \\
\hline & 120 & 0.380 & 60 & 0.400 & 40 & 0.325 & 50 & 0.296 & 40 & 0.259 & 40 & 0.330 \\
\hline & 170 & 0.491 & 80 & 0.472 & 60 & 0.401 & 60 & 0.342 & 60 & 0.321 & 50 & 0.393 \\
\hline & 240 & 0.626 & 110 & 0.548 & 70 & 0.430 & 80 & 0.410 & 70 & 0.344 & 60 & 0.409 \\
\hline & 330 & 0.728 & 245 & 0.650 & 80 & 0.479 & 110 & 0.462 & 80 & 0.394 & 80 & 0.473 \\
\hline & 430 & 0.800 & 185 & 0.741 & 110 & 0.561 & 120 & 0.501 & 110 & 0.472 & 100 & 0.548 \\
\hline & 600 & 0.891 & 230 & 0.786 & 145 & 0.637 & 145 & 0.542 & 145 & 0.551 & 120 & 0.588 \\
\hline & & & 280 & 0.853 & 185 & 0.730 & 185 & 0.600 & 185 & 0.615 & 150 & 0.652 \\
\hline & & & 330 & 0.905 & 230 & 0.783 & 230 & 0.665 & 230 & 0.685 & 180 & 0.717 \\
\hline & & & 390 & 0.940 & 280 & 0.831 & 280 & 0.744 & 280 & 0.738 & 240 & 0.808 \\
\hline & & & 450 & 0.954 & 330 & 0.871 & 330 & 0.784 & 390 & 0.836 & 300 & 0.860 \\
\hline & & & & & 390 & 0.915 & 390 & 0.834 & 500 & 0.886 & 380 & 0.901 \\
\hline & & & & & & & 450 & 0.880 & 600 & 0.930 & & \\
\hline & & & & & & & 570 & 0.923 & 720 & 0.955 & & \\
\hline $\mathrm{M}_{\infty}(\mathrm{mol} / \mathrm{kg})$ & \multicolumn{2}{|c|}{$8.00 \times 10^{-3}$} & \multicolumn{2}{|c|}{$5.73 \times 10^{-3}$} & \multicolumn{2}{|c|}{$4.41 \times 10^{-3}$} & \multicolumn{2}{|c|}{$1.65 \times 10^{-2}$} & \multicolumn{2}{|c|}{$1.65 \times 10^{-2}$} & \multicolumn{2}{|c|}{$5.90 \times 10^{-3}$} \\
\hline
\end{tabular}


Table 4 Kinetic data of the desorption of Dye 2 from nylon 6 film and the sorption of Dye 3 by polyester film.

\begin{tabular}{|c|c|c|c|c|c|c|c|c|c|c|c|c|c|c|}
\hline Dye and finten & \multicolumn{12}{|c|}{ Dye 2 from nylon 6 film } & \multicolumn{2}{|c|}{$\begin{array}{l}\text { Dye } 3 \text { on } \\
\text { polyester film }\end{array}$} \\
\hline Tenp. $\left({ }^{\circ} \mathrm{C}\right)$ & \multicolumn{2}{|r|}{50} & \multicolumn{2}{|r|}{60} & \multicolumn{4}{|c|}{70} & \multicolumn{4}{|c|}{80} & \multicolumn{2}{|r|}{95} \\
\hline $\begin{array}{l}\text { agitation } \\
\text { (strokes/min) }\end{array}$ & \multicolumn{2}{|r|}{30} & \multicolumn{2}{|r|}{30} & \multicolumn{2}{|r|}{30} & \multicolumn{2}{|c|}{146} & \multicolumn{2}{|r|}{30} & \multicolumn{2}{|c|}{146} & & 0 \\
\hline \multirow{17}{*}{ Kinetic data } & $\begin{array}{l}\text { Time } \\
(\min )\end{array}$ & $\mathrm{M}_{1} / \mathrm{M}_{\infty}$ & $\begin{array}{l}\text { Time } \\
\text { (min) }\end{array}$ & $M_{1} / M_{\infty}$ & $\begin{array}{l}\text { Time } \\
\text { (min) }\end{array}$ & $M_{t} / M_{\infty}$ & Time & $\mathrm{M}_{1} / \mathrm{M}_{\infty}$ & Time & $M_{1} / M_{\infty}$ & Time & $M_{1} / M_{x}$ & Time & $M_{1} / M_{\infty}$ \\
\hline & 3 & $0.077_{8}$ & 3 & 0.145 & 1 & 0.117 & 1 & 0.176 & 1 & 0.181 & 0.5 & 0.186 & 15 & 0.140 \\
\hline & 5 & 0.119 & 5 & 0.208 & 2 & 0.175 & 2 & 0.280 & 1.5 & 0.202 & 1 & 0.275 & 30 & 0.192 \\
\hline & 10 & 0.189 & 7 & 0.226 & 3 & 0.235 & 3 & 0.350 & 2 & 0.279 & 1.5 & 0.349 & 60 & 0.276 \\
\hline & 15 & 0.227 & 10 & 0.318 & 5 & 0.310 & 4.5 & 0.132 & 3 & 0.366 & 2 & 0.398 & 120 & 0.393 \\
\hline & 20 & 0.298 & 15 & 0.382 & 7 & 0.401 & 6 & 0.489 & 4 & 0.425 & 2.5 & 0.452 & 210 & 0.528 \\
\hline & 30 & 0.354 & 20 & 0.448 & 10 & 0.475 & 8 & 0.575 & 5 & 0.462 & 3.5 & 0.526 & 330 & 0.659 \\
\hline & 35 & 0.406 & 25 & 0.516 & 15 & 0.578 & 10 & 0.634 & 7 & 0.572 & 5 & 0.664 & 480 & 0.760 \\
\hline & 40 & 0.406 & 30 & 0.580 & 20 & 0.671 & 13 & 0.715 & 10 & 0.706 & 6 & 0.711 & 660 & 0.843 \\
\hline & 50 & 0.495 & 35 & 0.620 & 25 & 0.750 & 15 & 0.763 & 15 & 0.806 & 9 & 0.808 & 720 & 0.862 \\
\hline & 60 & 0.516 & 40 & 0.652 & 30 & 0.810 & 20 & 0.838 & 20 & 0.889 & 10 & 0.826 & & \\
\hline & 80 & 0.610 & 50 & 0.719 & 35 & 0.862 & 30 & 0.903 & 25 & 0.914 & 15 & 0.910 & & \\
\hline & 110 & 0.703 & 60 & 0.784 & 40 & 0.898 & 40 & 0.942 & 30 & 0.960 & 20 & 0.931 & & \\
\hline & 145 & 0.775 & 80 & 0.863 & 50 & 0.927 & & & 35 & 0.977 & & & & \\
\hline & 185 & 0.856 & 90 & 0.893 & 60 & 0.949 & & & & & & & & \\
\hline & 230 & 0.899 & 110 & 0.925 & & & & & & & & & & \\
\hline & 280 & 0.959 & & & & & & & & & & & & \\
\hline $\mathrm{M}_{\infty}(\mathrm{mol} / \mathrm{kg})$ & \multicolumn{2}{|c|}{$1.65 \times 10^{-2}$} & \multicolumn{2}{|c|}{$1.65 \times 10^{-2}$} & \multicolumn{2}{|c|}{$1.65 \times 10^{-2}$} & \multicolumn{2}{|c|}{$5.90 \times 10^{-3}$} & \multicolumn{2}{|c|}{$1.65 \times 10^{-2}$} & \multicolumn{2}{|c|}{$5.90 \times 10^{-3}$} & & \\
\hline
\end{tabular}

Table 5 Estimation of the thickness of diffusional boundary layer $(\delta \mathrm{D})$ for each film dyeing systen.

\begin{tabular}{|c|c|c|c|c|c|c|c|c|}
\hline Dye & $\begin{array}{c}\text { Temp } \\
\left({ }^{\circ} \mathrm{C}\right)\end{array}$ & $\begin{array}{c}\text { Stirring } \\
\text { (strokes/min) }\end{array}$ & $\begin{array}{l}\left.\mathrm{D}_{\mathrm{f}} \times 10^{9} \quad \mathrm{c}\right) \\
\left(\mathrm{cm}^{2} / \mathrm{min}\right)\end{array}$ & L & K & $\begin{array}{l}\left.\mathrm{D}_{\mathrm{s}} \times 10^{4} \mathrm{~d}\right) \\
\left(\mathrm{cm}^{2} / \mathrm{min}\right)\end{array}$ & $\begin{array}{c}1 \times 10^{3} \\
(\mathrm{~cm})\end{array}$ & $\begin{array}{c}\delta_{\mathrm{v}} \times 10^{3} \\
(\mathrm{~cm})\end{array}$ \\
\hline $1^{3}$ & 40.0 & $\begin{array}{r}0 \\
30 \\
80 \\
\end{array}$ & 4.84 & $\begin{array}{c}3.08 \\
12.4 \\
17.1\end{array}$ & 494 & 4.29 & $\begin{array}{l}1.37_{8} \\
1.27_{5} \\
1.33_{5} \\
\end{array}$ & $\begin{array}{l}80.2 \\
18.5 \\
14.0 \\
\end{array}$ \\
\hline \multirow{5}{*}{$2^{\text {a? }}$} & 40.0 & $\begin{array}{r}30 \\
80 \\
146 \\
\end{array}$ & 4.07 & $\begin{array}{r}7.03 \\
8.13 \\
167\end{array}$ & 1120 & 4.11 & $\begin{array}{l}1.28_{6} \\
1.32_{0} \\
1.31_{5}\end{array}$ & $\begin{array}{c}16.5 \\
14.6 \\
0.71 \\
\end{array}$ \\
\hline & 50.0 & 30 & 10.0 & 9.00 & 724 & 5.07 & $1.39_{0}$ & 10.8 \\
\hline & 60.0 & 30 & 24.9 & 5.80 & 565 & 6.13 & $1.34_{3}$ & 10.1 \\
\hline & 70.0 & $\begin{array}{r}30 \\
146\end{array}$ & 55.0 & $\begin{array}{r}6.25 \\
222\end{array}$ & 390 & 7.30 & $\begin{array}{l}1.379 \\
1.30_{5}\end{array}$ & $\begin{array}{l}7.51 \\
0.20\end{array}$ \\
\hline & 80.0 & $\begin{array}{r}30 \\
146 \\
\end{array}$ & 125 & $\begin{array}{r}5.00 \\
142 \\
\end{array}$ & 322 & 8.57 & $\begin{array}{l}1.39_{\mathrm{s}} \\
1.37_{\mathrm{g}}\end{array}$ & $\begin{array}{l}5.94 \\
0.21 \\
\end{array}$ \\
\hline $3^{6)}$ & 95.0 & 0 & 0.374 & 280 & 367 & 13.2 & 0.600 & 20.6 \\
\hline
\end{tabular}

3) Desorption (rom the nylon 6 film into aqueous bath at zero dye concentration.

b) Sorption from an infinite dye bath by the polyester film.

"Determined from the concentration profile of dye in the film.

") Estimated from van der Waals volume of dye. ${ }^{8.9}$

can estimate the value of $\delta_{\mathrm{D}}$ for each film dyeing system on assumption that the flow near the film is laminar one. The values of $\delta$ D estimated by eq. 5 , however, may be taken as an indication of the thickness of diffusional boundary layer for the film dyeing since the prerequisites required to apply eq. 5 to the film dyeing system have not been verified yet. Table 6 shows the comparison of the values of $\delta_{D}$ estimated in present study for the film dyeing with those estimated from kinetic data of yarn dyeing ${ }^{3)}$ and with the values of $\delta_{\mathrm{D}}$ calculated by eq. 5 .

McGregor et al. ${ }^{1)}$ predicted theoretically that for dyeing from unstirred dye bath, the sorption behavior corresponds to $2<\mathrm{L}<10$, and that from good stirring corresponds to $\delta \mathrm{D}=\mathrm{ca} .3 \times 10^{-3} \mathrm{~cm}$. The experimental values of $\delta_{\mathrm{D}}$ obtained in this study are discussed briefly 
Table 6 Comparison of the values of $\delta_{\mathrm{D}}$ estimated from kinetic data of film dyeing with those estimated from kinetic data of yarn dyeing and the values of $\delta_{\mathrm{D}}$ calculated by eq. 5 .

\begin{tabular}{|c|c|c|c|c|c|c|}
\hline \multirow{3}{*}{$\begin{array}{l}\text { Temp. } \\
\left({ }^{\circ} \mathrm{C}\right)\end{array}$} & \multirow{3}{*}{ Dye } & \multirow{3}{*}{$\begin{array}{l}\text { Agitation" } \\
\text { (strokes/min) }\end{array}$} & \multicolumn{3}{|c|}{$\begin{array}{l}\text { Estimated from kinetic } \\
\text { data of dyeing }\end{array}$} & \multirow{3}{*}{$\frac{\frac{c_{\text {Calculated }}^{\text {b) }}}{\text { by eq. } 5}}{\text { film }}$} \\
\hline & & & \multicolumn{2}{|c|}{ film } & \multirow{2}{*}{ 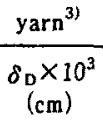 } & \\
\hline & & & $L$ & $\begin{array}{c}8 \mathrm{D} \times 10^{3} \\
(\mathrm{~cm})\end{array}$ & & \\
\hline \multirow{9}{*}{40.0} & \multirow{5}{*}{1} & 0 & 3.08 & 80.2 & 181 & \\
\hline & & 30 & 12.4 & 18.5 & 37.0 & 10.0 \\
\hline & & 50 & & & 27.8 & 7.75 \\
\hline & & 80 & 17.1 & 14.0 & 2.0 & 6.13 \\
\hline & & 146 & & & 2.7 & 4.54 \\
\hline & \multirow{4}{*}{2} & 30 & 7.03 & 16.5 & & 9.87 \\
\hline & & 50 & & & 25.8 & 7.64 \\
\hline & & 80 & 8.13 & 14.6 & & 6.04 \\
\hline & & 146 & 167 & 0.71 & & 4.47 \\
\hline \multirow{2}{*}{50.0} & 1 & 50 & & & 10.1 & 8.08 \\
\hline & 2 & 30 & 9.00 & 10.8 & & 10.3 \\
\hline \multirow{2}{*}{60.0} & 1 & 50 & & & 5.8 & 8.39 \\
\hline & 2 & 30 & 5.80 & 10.1 & & 10.7 \\
\hline \multirow{2}{*}{70.0} & \multirow{2}{*}{2} & 30 & 6.25 & 7.51 & & 11.1 \\
\hline & & 146 & 222 & 0.20 & & 5.01 \\
\hline \multirow{2}{*}{80.0} & \multirow{2}{*}{2} & 30 & 5.00 & 5.94 & & 11.4 \\
\hline & & 146 & 142 & 0.21 & & 5.18 \\
\hline 95.0 & 3 & 0 & 280 & 20.6 & 592 & \\
\hline
\end{tabular}

a) Agitation of $30,50,80$ and 146 strokes/min correspond to the average velocity of the reciprocation of the specimen of $3.0,5.0,8.0$, and $14.6 \mathrm{~cm} / \mathrm{sec}$, respectively. ${ }^{\circ)}$ Calculated by eq. 5 using $\lambda=2.0 \mathrm{~cm}$

from the view point of the theoretical prediction de. scribed above. The experimental values of $\mathrm{L}$ estimated for unstirred systems were 3.08 (the desorption of Dye 1 from nylon 6) and 280 (sorption of Dye 3 by polyester film), respectively. The former agrees well with the pre. dicted value, whereas the latter is much larger than that predicted. However, the deviation of the latter from the predicted value may be attributable to the very small value of $\mathrm{D}_{\mathrm{f}}$ since the value of $\delta_{\mathrm{D}} 20.6 \times 10^{-3} \mathrm{~cm}$, calcu. lated using $\mathrm{L}=280$ seems to be reasonable. The values of $\delta_{D}$ in the film dyeing systems decreased as the rate of agitation of the specimen was increased, particularly up to $146 \mathrm{strokes} / \mathrm{min}(14.6 \mathrm{~cm} / \mathrm{sec})$ at which the $\delta_{\mathrm{D}}$ values decreased to $2.0-7.1 \times 10^{-4} \mathrm{~cm}$; these values are much smaller than the predicted value but close to the values of $\delta_{\mathrm{D}}$ at the surface of cellulose membrane, $3.8-5.9 \times$ $10^{-4} \mathrm{~cm},{ }^{3)}$ which were estimated by measuring the per. meability of Dye 2 through the multilayer of the membrane under vigorous stirring at $30^{\circ} \mathrm{C}$. The predicted value, $\delta_{\mathrm{D}}=\mathrm{ca} .3 \times 10^{-3} \mathrm{~cm}$ for dyeing from well stirred solution, may be referred to the dyeing of fiber assem. blies, in which the rate of fluid flow at the surface of the individual fiber is much lower than that of the bulk flow. The small values of $\delta_{\mathrm{D}}$ estimated for the film dyeing under the agitation of 146 strokes/min indicate that in the dyeing of films from well stirred solution, the resist. ance to the dye transport across the diffusional boundary layer gives little effect on the rate of dyeing, in contrast to the dyeing of packed yarns of fabrics.

McGregor et al. have also estimated the values of $\delta D$ in a film dyeing with acid dyes from the kinetic data of dye sorption by the film; $17.2-4.1 \times 10^{-3} \mathrm{~cm}$ at the bulk flow of $4.2-10.0 \mathrm{~cm} / \mathrm{sec}, 67^{\circ} \mathrm{C}^{10)}$ The values of $\delta \mathrm{D}$ obtained in this study (the fifth column of Table 6) are comparable with those estimated by McGregor et al.

The comparison of the values of $\delta_{\mathrm{D}}$ estimated for the film dyeing with those for the yarn dyeing with the same dyes $^{3)}$ (the sixth column of Table 6) indicates that the value of $\delta_{\mathrm{D}}$ in the film dyeing is, as a whole, smaller than that of yarn dyeing ${ }^{3)}$ under the same stirring condi. tions, particularly under the vigorous agitation, though in some cases the values of $\delta_{\mathrm{D}}$ in the film dyeing are larger than those of corresponding yarn dyeing. This is a result of the fact that the flow rate of dye liquor in the yarn is lower than that at the film surface. However, the difference in $\delta_{\mathrm{D}}$ between the film dyeing and the yarn dyeing seems to be rather smaller than that predicted intuitively except for the values of $\delta_{0}$ estimated under the agitation 
of 146 strokes $/ \mathrm{min}$. This is ascribed to the fact that in the previous work, ${ }^{3}$. only a thread of the yarn hanged loosely on a holder was dyed in an infinite bath, the dye liquor can permeate more easily under such conditions than in the practical yarn dyeing, in which yarns are packed tightly to some extent; the permeation of the fluid in the packed yarn is more difficult.

The values of $\delta \mathrm{p}$ obtained in the present study under the agitation of $30-80$ strokes/min are also comparable with those calculated by eq. 5 , although the values of $\delta_{\mathrm{D}}$ obtained under the agitation of 146 strokes/min are much smaller than those calculated. However, if we consider that the values of $\delta \mathrm{o}$ calculated by eq. 5 may be taken as an indication of the thickness of diffusional boundary layer as described before, the agreement be. tween them seems to be satisfactory.

The authors are grateful to Unitika Ltd., Toray Ltd. and $\mathrm{Dr}$. 1. Abe for the gifts of nylon $6 \mathrm{fim}$, polyester film and active carbon fiber, respectively.

The most parts of this study were presented at 78 th Meeting of No. 120 Committee (Dyeing and Finishing) of
Science Promotion Society Japan. held at January 30 , 1988, Tokyo, Japan

\section{REFERENCES}

1) R. McGregor, J. Soc. Dyers Colour., 81, 429 (1965)

2) R. McGregor and R. H. Peters, J. Soc. Dyers Colour., 81, 393 (1965)

3) T. Shibusawa, T. Endo, Y. Kameta and P. Rys, Sen-i Gakkaishi. 42, T-671 (1986)

4) R. McGregor, A. E. Nounou and R. H. Peters, I. Soc. Dyers Colour., 90, 246 (1974)

5) J. Crank, "The Mathematics of Diffusion, second ed." Clarendon Press, Oxford, 60 (1975)

6) J. N. Etters, J. Soc. Dyers Colour., 97, 170 (1981)

7) M. Sekido, T. lijima and A. Takahashi, Kogyo Kagaku Zasshi 68, 524 (1965), T. Shibusawa and T. lijima, Appl. Polymer Sci. 14, 1553 (1970), A. Datyner, M. J. Delaney and T. Iijimn. Text. Res. J., 43, 48 (1973)

8) T. Shibusawa, Sen-i Gakkaishi, 43. 1987 (1987)

9) A. Bondi, J. Phys. Chem., 68, 441 (1964)

10) R. McGregor, R. H. Peters and K. Varol, J. Soc. Dyers Colour., 86. 437 (1970)

\section{フィルムの染色速度データからの 拡散の境界層の厚さの見瞽り}

\section{群馬大学工業短期大学部 啮沢崇男・遠藤智道}

非仿ン染料の十イロン6フィルム加らの水中への脱 着速度と無限浴からポリエチレンテレフタラートフィル 么の染色速度を漬定した。得られた染色速度データに対 してNewman 式を用いた曲線のあてはめを行ない、フ イルム中の染料の应散係数 $\left(\mathrm{D}_{f}\right)$ 並びに境界層バラメー 夕（し）を求めた。同じ染料一フィルム系についてフィ ル卷廨法で $\mathrm{D}_{\mathrm{f}}$ 求めた。雨法で求めた $\mathrm{D}_{\mathrm{f}}$ の值は多く の婸合証一致したが，ナイロン6フィルムに高い親和力 持つ染料が拍䢁が不十分な染浴中で脱着される時は， 脱着速度デー夕から得られたD，の値はフィルム巻尿法 からのそれよりかないさな值となった。

一段に，港度分布曲線加ら得られる D,の值は染色速 度データからのそれらよりも櫭頼性が高い。この点を考 唯して，测定された染色速度 (脱着速度) デー夕に対し て, Newman式にフィルム卷曆法で得られた $\mathrm{D}_{\mathrm{f}}$ を入れ て曲線のあて浪めを行なって，Lの值を求め。これより
各フイルム染色系の搪散の境界層の厚さ $\left(\delta_{D}\right)$ を見皘 もった。得られた值は試料の浴中の㩭找速度（上下方向 $30 \mathrm{~mm}$ の往復運動) が0，30，80及び 146strokes/minの 時, $\delta_{D}=20-80,5.9-18.5,14-15 及 ひ 00.2-0.7 \times$ $10^{-3} \mathrm{~cm}$ 程度であった。これらの㨁を同じ染料でナイ口 ン6，ポリエステル紡續系を染色した時に見積もられて

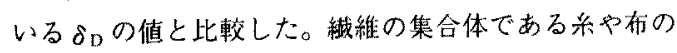

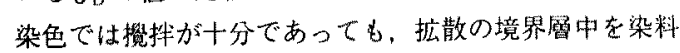
が透過する速度が染色速度に影暨を与えるが, フィルム 染色系では基質の近傍の染液流速が $14.6 \mathrm{~cm} / \mathrm{sec}$ 柽度ま

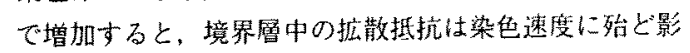
響を与えないことが分加った。

この報告で見積もられた $\delta_{D}$ の値は，酸性染料による

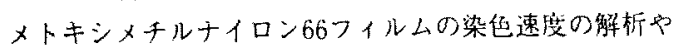
流体力学に基つく Levichの式で計算した結果上はぼ 致した。 